ABDIHAZ: Jurnal Ilmiah Pengabdian pada Masyarakat
LPPM UNIHAZ
https://journals.unihaz.ac.id/index.php/abdihaz

\title{
Pelatihan Pembuatan Keju untuk Memenuhi Kebutuhan Nutrisi Tulang dan Gigi Anak Masa Golden age
}

\section{The Training of Making Cheese to Meet the Nutritional Needs of Children's Bones and Teeth during the Golden Age}

\author{
Rahmawida Putri $^{1 *}$, Haerul Juhroni ${ }^{2}$ \\ ${ }^{1}$ Program Studi Farmasi, Sekolah Tinggi Farmasi Muhammadiyah Tangerang, Jl. K.H. Syekh Nawawi KM 4 No. 13 \\ Matagara, Tigaraksa, Indonesia \\ ${ }^{2}$ Program Studi Managemen, Sekolah Tinggi Ilmu Ekonomi Banten, Jl. Let. Jidun No 7-C Kepandean, Kota Serang, \\ Banten, Indonesia
}

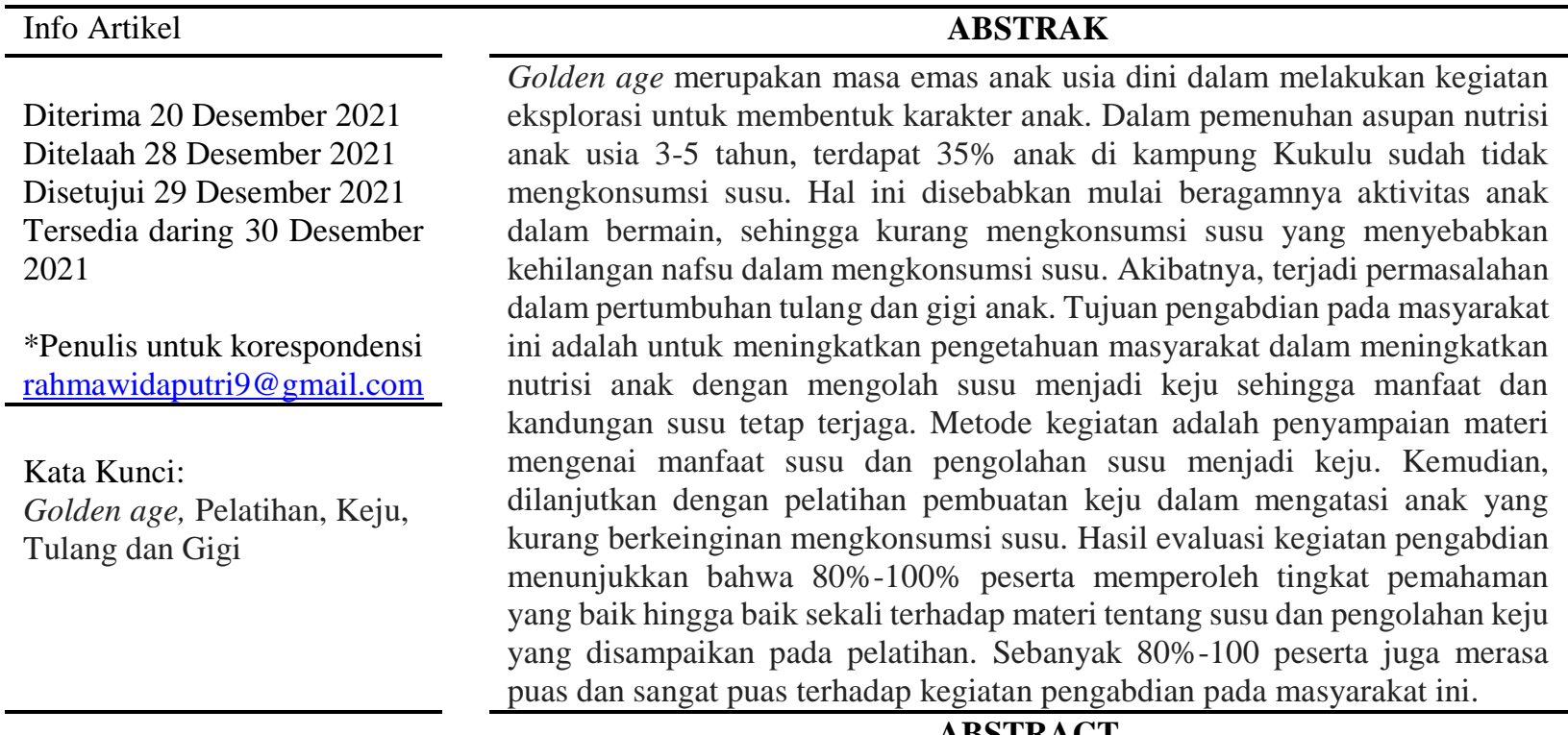

Keywords:

Bones and Teeth, Cheese, Golden age, Training

Golden age is a golden period of early childhood in conducting exploration activities in shaping children's character. In fulfilling the nutritional intake of children aged 3-5 years, there are 35\% of children in Kukulu village who do not consume milk. This is due to the start of various activities of children in playing, so less consumption of milk. It causes the loss of appetite in consuming milk so that there are problems in the growth of children's bones and teeth. The purpose of program was to increase public knowledge in improving children's nutrition by processing milk into cheese so that the benefits and content of milk are maintained. The method of this community service was lecturing about the benefits of milk and the processing into cheese. Than, continued with training of cheese making in overcoming children who are less willing to consume milk. Evaluation data showe that about $80 \%-100 \%$ of the participants got the good and very good understanding about the material. And, about $80 \%-100 \%$ of them satisfied with satisfied with it.

ISSN 2685-0354 (Media Online). Diterbitkan oleh Universitas Prof. Dr. Hazairin, SH. Ini merupakan jurnal bebas akses di bawah lisensi Creative Commons Atribution 4.0 International. 


\section{PENDAHULUAN}

Golden age merupakan masa emas anak usia dini dalam melakukan kegiatan eksplorasi dalam membentuk karakter anak. Hal ini sejalan dengan hasil riset Uce (2017) yang mengungkapkan bahwa 4 tahun pertama merupakan fase penting dalam pertumbuhan dan perkembangan anak. Fase ini sama pentingnya dengan 14 tahun berikutnya hingga pertumbuhan dan perkembangan anak berhenti. Dalam pertumbuhan dan perkembangan anak, orangtua mempunyai andil yang sangat penting, salah satunya adalah dalam memberikan nutrisi pada anak. Hal ini sudah tercantum dalam hadis Rasulullah SAW "setiap anak dilahirkan di atas fitrah (kesucian agama yang sesuai dengan naluri), sehingga lancar lidahnya, maka kedua orangtua yang menjadikan dia beragama Yahudi, Nasrani, atau Majusi”(H.R. Bukhori) (Nuryati, 2017).

Clark dalam Kertamuda (2015) mengutarakan bahwa otak anak usia dini terdiri dari 100200 miliar neuron. Namun karena kurangnya stimulasi dan asupan nutrisi pada anak, potensi neuron anak yang berkembang hanya berkisar antara 5-10\%. Pertumbuhan anak pada usia golden age sangat bergantung pada asupan nutrisi yang diserap oleh tubuh. Makanan yang dikonsumsi anak berperan penting dalam pertumbuhan dan perkembangan sel otak dan tubuhnya (Rahmi, 2019).

Dalam pemenuhan asupan nutrisi anak usia 3-5 tahun, sebanyak 35\% anak di kampung Kukulu Desa Dangdeur Kecamatan Jayanti Kabupaten Tangerang, Banten sudah tidak mengkonsumsi susu. Hal ini disebabkan mulai beragamnya aktivitas anak dalam bermain, sehingga kurang mengkonsumsi susu yang menyebabkan kehilangan nafsu dalam mengkonsumsi susu (Damayanti, 2013). Perilaku ini membuat persoalan baru terhadap anak. Salah satunya adalah keterlambatan pertumbuhan tulang dan gigi. Pertumbuhan tulang dan gigi anak semakin menurun akibat kekurangan kalsium dalam nutrisi yang dikonsumsi sehari-hari (Hidayat, 2010). Permasalahan ini akan meningkat menjadi masalah kekerdilan (stunting) pada anak.

Pertumbuhan tulang dan gigi anak berpengaruh sangat penting terhadap pertumbuhan anak di masa remaja. Banyak anak di masa golden age sudah mengalami kerusakan gigi seperti keropos, busuk, maupun gigi bolong yang menyebabkan sakit gigi pada anak (Afrinis, et al., 2020). Selain itu, menurut Siahaan et al. (2015), kerapuhan tulang pada anak karena komposisi kepadatan tulang berkurang yang disebabkan oleh rendahnya asupan kalsium yang berperan penting dalam pertumbuhan tulang. Dari 250 juta anak penduduk Indonesia, terdapat 75 juta anak mengalami kerusakan pada gigi (Maulani, 2005). Hal ini juga selaras dengan observasi yang dilakukan pada 20 anak usia golden age (1-5 tahun) di Kampung Kukulu RT 05 RW 04. Terdapat 15 anak yang sudah mengalami kerusakan gigi dan terdapat 10 anak mengalami pertumbuhan tulang yang lambat seperti lambat berjalan dan memiliki ukuran tinggi badan yang tidak sesuai dengan usianya.

Konsumsi susu yang banyak memberi rasa tidak enak pada lidah anak-anak. Ini menyebabkan anak kehilangan keinginan untuk mengkonsumsi susu. Selain itu, susu yang sudah diolah tidak tahan lama sehingga harus dibuang. Hal ini dapat diatasi dengan mengolah susu menjadi bahan makanan lain yang disukai anak dan dapat bertahan dalam jangka waktu cukup panjang. Pengolahan susu salah satunya dapat dijadikan olahan keju. Menurut Fitri (2020) pembuatan keju dapat meningkatkan kreativitas ibu rumah tangga dalam menyediakan jajanan anak yang sehat dan halal. Selain itu, keju juga dapat menjadi toping tambahan makanan seperti dalam pembuatan salad buah (Nirmala \& Aisyah, 2018) sehingga selain menambah asupan kalsium bagi anak dari segi konsumsi keju juga dapat menambah nutrisi vitamin bagi anak dari segi konsumsi buah. 
Pengolahan susu menjadi keju menjadi salah satu alternatif yang kreatif bagi anak yang sudah tidak suka dengan rasa susu. Sehingga, kegiatan pengabdian pada masyarakat ini bertujuan agar pemenuhan asupan nutrisi terutama kalsium pada anak berusia golden age (1-5 tahun) di Kampung Kukulu RT 005 RW 004 Desa Dandeur Kecamatan Jayanti Kabupaten Tangerang, Banten dapat meningkat.

\section{METODE}

Kegiatan pengabdian masyarakat dilakukan selama bulan Desember 2021 mulai dari persiapan hingga evaluasi. Kegiatan ini dilaksanakan di salah satu rumah warga yang berperan sebagai Ketua Pemberdayaan Kesejahteraan Keluarga (PKK) Kp. Kukulu RT 005 RW 004 Desa Dangdeur Kecamatan Jayanti Kabupaten Tangerang, Banten.

Tabel 1 Angket pengetahuan dan pemahaman masyarakat

\begin{tabular}{|c|c|c|c|c|c|c|}
\hline No & Pernyataan & Kurang & Sedikit & Biasa & Baik & Baik Sekali \\
\hline 1 & Saya mengetahui jenis susu & & & & & \\
\hline 2 & Saya mengetahui manfaat susu & & & & & \\
\hline 3 & $\begin{array}{l}\text { Saya mengetahui dampak negatif kurang } \\
\text { konsumsi susu bagi anak golden age }\end{array}$ & & & & & \\
\hline 4 & Saya mengetahui macam-macam olahan susu & & & & & \\
\hline 5 & Saya mengetahui manfaat keju & & & & & \\
\hline 6 & Saya mengetahui proses pembuatan keju & & & & & \\
\hline
\end{tabular}

Tabel 2 Angket Kepuasan Masyarakat Terhadap Kegiatan Pengabdian

\begin{tabular}{|c|c|c|c|c|c|c|}
\hline No & Pernyataan & $\begin{array}{c}\text { sangat } \\
\text { puas }\end{array}$ & puas & $\begin{array}{c}\text { cukup } \\
\text { puas }\end{array}$ & $\begin{array}{c}\text { kurang } \\
\text { puas }\end{array}$ & $\begin{array}{l}\text { tidak } \\
\text { puas }\end{array}$ \\
\hline 1 & Hasil kegiatan bermanfaat bagi saya & & & & & \\
\hline 2 & Hasil kegiatan bermanfaat bagi tempat saya & & & & & \\
\hline 3 & Hasil kegiatan sesuai dengan kebutuhan saya & & & & & \\
\hline 4 & Hasil kegiatan sesuai kebutuhan masyarakat setempat & & & & & \\
\hline 5 & Hasil kegiatan sesuai dengan minat saya & & & & & \\
\hline 6 & Hasil kegiatan mendukung pengembangan setempat & & & & & \\
\hline 7 & $\begin{array}{l}\text { Hasil kegiatan dapat menyelesaikan permasalahan } \\
\text { yang terjadi di daerah tempat tinggal saya }\end{array}$ & & & & & \\
\hline 8 & Hasil kegiatan menyelesaikan permasalahan saya & & & & & \\
\hline 9 & Hasil kegiatan dapat memberdayakan masyarakat & & & & & \\
\hline 10 & Saya merasa senang dengan terlaksananya kegiatan & & & & & \\
\hline 11 & Saya ikut terlibat secara aktif selama proses kegiatan & & & & & \\
\hline 12 & Panitia yang melaksanakan kegiatan ramah dan sopan & & & & & \\
\hline 13 & Panitia yang melaksanakan kegiatan memotivasi kami & & & & & \\
\hline 14 & Panitia kegiatan mampu memberdayakan kami & & & & & \\
\hline
\end{tabular}

Kegiatan pengabdian pada masyarakat diawali dengan pemberian angket sebelum penyampaian materi dan dilanjutkan dengan pemberian materi. Kegiatan penyuluhan ditutup dengan pemberian angket setelah penyuluhan untuk mengetahui tingkat pengetahuan dan pemahaman masyarakat terhadap materi yang disampaikan. Angket yang diberikan kepada 
masyarakat berisi 6 pernyataan yang berkaitan dengan materi tentang manfaat susu serta pengolahan susu menjadi olahan keju (Tabel 1).

Kegiatan dilanjutkan dengan memberikan pelatihan praktik pengolahan susu menjadi olahan keju yang dapat menjadi pengganti susu yang diminati oleh anak-anak agar nutrisi yang dibutuhkan oleh anak usia golden age tertap terpenuhi. Proses pembuatan keju memerlukan alat berupa panci, kompor, sendok pengaduk, wadah, serta sendok. Sementara bahan yang diperlukan berupa susu segar ultra high temperature (UHT) full cream, garam, dan cuka makan. Kegiatan pengabdian diakhiri dengan pemberian angket mengenai kepuasan masyarakat terhadap kegiatan yang dilakssanakan (Tabel 2).

\section{HASIL DAN PEMBAHASAN}

Sekolah Tinggi Farmasi Muhammadiyah Tangerang (STFM) sebagai institusi pendidikan tinggi kesehatan di bidang farmasi melakukan kegiatan pengabdian kepada masyarakat dengan melakukan pelatihan pembuatan keju untuk memenuhi kebutuhan nutrisi tulang dan gigi anak masa golden age. Penyuluhan mengenai manfaat susu dan bagaimana pengolahan susu menjadi keju dan manfaat keju bagi pertumbuhan dan perkembangan tulang dan gigi bagi anak usia golden age dilakukan pada kegiatan ini (Gambar 1).

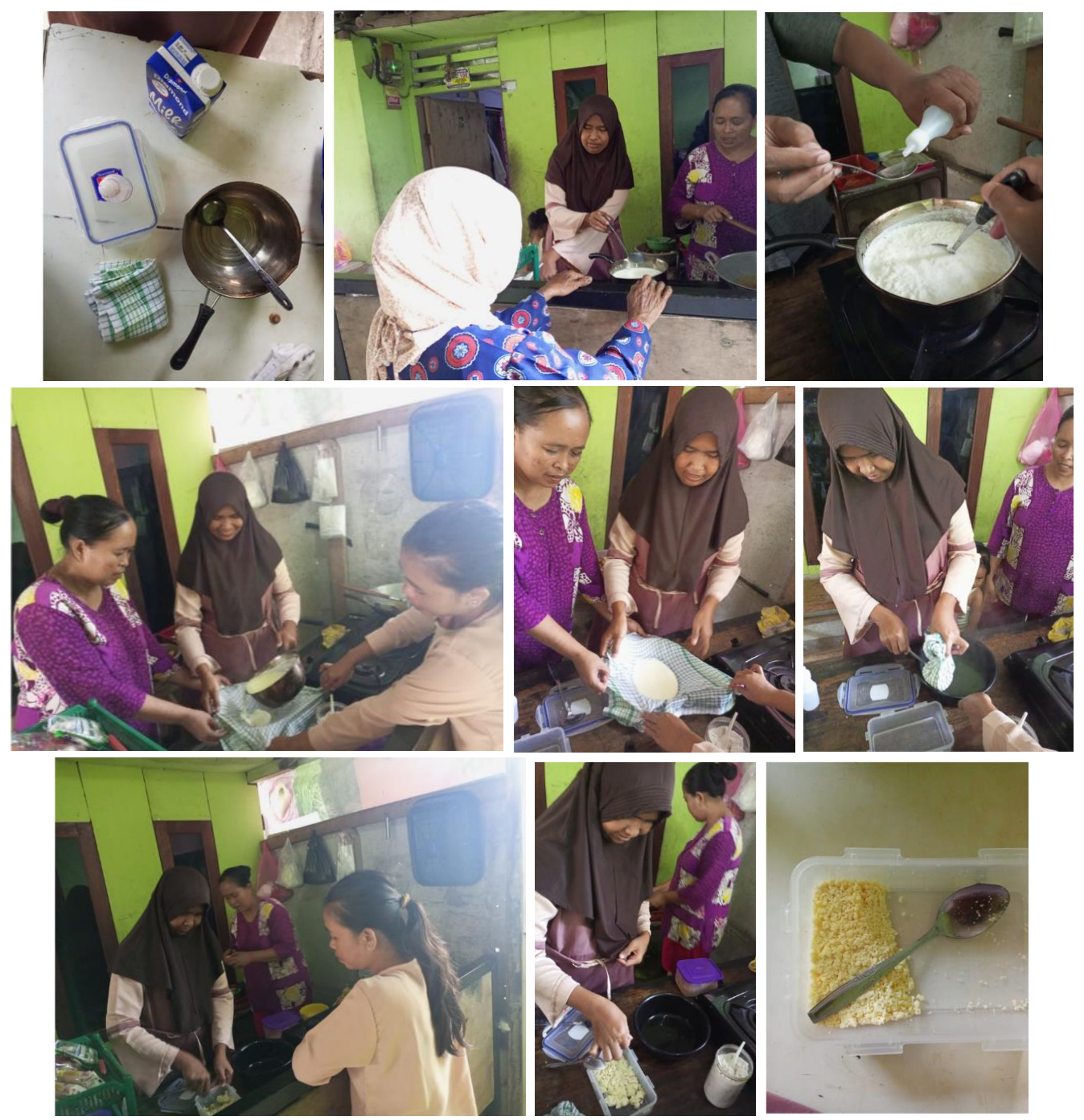

Gambar 1 Proses kegiatan pengolahan menjadi keju 
Penyuluhan dan pelatihan yang dilaksanakan menambah pemahaman masyarakat mengenai keju. Keju adalah sebuah makanan yang dihasilkan dengan memisahkan zat-zat padat dalam susu melalui proses pengentalan atau koagulasi (Negara et al., 2016). Proses pengentalan ini dilakukan dengan bantuan bakteri atau enzim tertentu yang disebut rennet. Hasil dari proses tersebut dikeringkan, diproses, dan diawetkan dengan berbagai macam cara. Menurut Riwayati et al. (2018), susu dengan kandungan kalsium yang tinggi dapat diolah menjadi berbagai variasi produk keju. Produk-produk keju bervariasi ditentukan dari tipe susu, metode pengentalan, temperatur, metode pemotongan, pengeringan, pemanasan, juga proses pematangan keju dan pengawetan.

Keju merupakan salah satu produk olahan susu yang dapat dikonsumsi sebagai camilan atau diolah menjadi berbagai jenis makanan dan kue kering. Tak hanya lezat, keju juga dikenal sebagai sumber nutrisi yang baik bagi tubuh. Apabila dikonsumsi dengan tepat, keju dapat memberikan banyak manfaat untuk kesehatan. Negara et al. (2016) menjelaskan dalam penelitiannya bahwa keju juga mengandung omega-3, asam amino sistein, serta beragam jenis antioksidan, seperti riboflavin, beta karoten, dan glutathione.

Tabel 3 Pemahaman masyarakat mitra mengenai keju setelah kegiatan terlaksana

\begin{tabular}{llccccc}
\hline No & \multicolumn{1}{c}{ Pernyataan } & Kurang & Sedikit & Biasa & Baik & $\begin{array}{c}\text { Baik } \\
\text { Sekali }\end{array}$ \\
\hline 1 & Saya mengetahui jenis susu & 0 & 0 & 2 & 3 & 5 \\
2 & Saya mengetahui manfaat susu & 0 & 0 & 1 & 3 & 6 \\
3 & $\begin{array}{l}\text { Saya mengetahui dampak negatif kurang } \\
\text { konsumsi susu bagi anak golden age }\end{array}$ & 0 & 0 & 0 & 2 & 8 \\
4 & Saya mengetahui macam-macam olahan susu & 0 & 0 & 2 & 2 & 6 \\
5 & Saya mengetahui manfaat keju & 0 & 0 & 1 & 1 & 8 \\
6 & Saya mengetahui proses pembuatan keju & 0 & 0 & 0 & 1 & 9 \\
\hline
\end{tabular}

Menurut Abdul Aziz (2010) terdapat beberapa manfaat yang dapat diperoleh dengan rutin mengonsumsi keju, yaitu memelihara kekuatan dan kesehatan tulang, menjaga kesehatan gigi, menyehatkan saluran pencernaan, menurunkan tekanan darah, menurunkan risiko terjadinya penyakit jantung, dan meredakan peradangan dalam tubuh. Sebagai salah satu jenis produk olahan susu, keju diketahui bermanfaat untuk memelihara kekuatan dan kesehatan tulang. Ini berkat kandungan kalsium dan protein yang melimpah di dalamnya. Tak hanya kalsium, kandungan protein, zinc, vitamin $A$, vitamin $D$, dan vitamin $K$, dalam keju juga diketahui bermanfaat baik untuk menjaga kesehatan tulang. Dengan mencukupi asupan nutrisi tersebut, Anda pun dapat terhindar dari berbagai masalah tulang, misalnya osteoporosis.

Tak hanya memelihara kekuatan tulang, keju juga bermanfaat untuk menjaga kesehatan gigi. Hal ini didukung oleh beberapa penelitian yang membuktikan bahwa keju dapat melindungi gigi dari risiko gigi berlubang. Bahkan, ada juga penelitian yang menunjukkan bahwa anak-anak yang mengonsumsi lebih banyak produk olahan susu, termasuk keju, memiliki risiko gigi berlubang yang lebih kecil daripada anak-anak yang tidak mengonsumsi susu dan produk olahannya.

Keju merupakan salah satu jenis makanan yang diolah dengan cara fermentasi. Cara pengolahan ini membuat keju mengandung bakteri probiotik yang diketahui baik untuk menjaga kesehatan saluran pencernaan. Meski demikian, mengonsumsi terlalu banyak keju justru dapat 
menyebabkan konstipasi. Tak hanya itu, pada beberapa orang yang tidak dapat mencerna laktosa, keju dapat menyebabkan masalah pada pencernaan, seperti diare.

Keju diduga dapat mengontrol tekanan darah dan mencegah hipertensi. Ini karena kandungan kalsium yang tinggi di dalamnya. Agar dapat memperoleh khasiat keju untuk menurunkan tekanan darah dengan maksimal, Anda disarankan memilih keju yang rendah lemak dan garam, seperti keju ricotta dan keju cottage.

Beberapa penelitian menunjukkan bahwa mencukupi konsumsi produk olahan susu, seperti keju dan yoghurt, dapat menurunkan risiko terjadinya penyakit kardiovaskuler, seperti penyakit jantung dan stroke. Meski demikian, masih diperlukan penelitian lebih lanjut mengenai efektivitas dan tingkat keamanan konsumsi keju untuk menjaga kesehatan jantung.

Hingga saat ini, produk olahan susu, termasuk keju, dianggap sebagai jenis makanan yang dapat memicu peradangan di dalam tubuh. Padahal, beberapa penelitian menunjukkan bahwa keju mengandung linoleic acid, sejenis asam lemak yang diketahui mampu meredakan peradangan. Bahkan, asam lemak ini juga dipercaya dapat menurunkan berat badan.

Susu memiliki kandungan protein bermanfaat untuk pertumbuhan anak, kalsium untuk kepadatan tulang atau tempat jaringan menempel, sementara vitamin D meningkatkan penyerapan kalsium (Widodo, 2002). Louisa (2017) menjelaskan fungsi vitamin D dalam bukunya "Berbagai Manfaat Vitamin D" bahwa vitamin D juga berperan dalam kesehatan pencernaan terutama mikrobiota untuk meningkatkan penyerapan zat gizi dan memberikan respons peningkatan kinerja sel-sel darah putih dalam daya tahan tubuh serta memberikan respons pada otak untuk mengeluarkan hormon bahagia

Masyarakat akhirnya mengetahui cara membuat keju. Kegiatan pengabdian yang diisi dengan pelatihan praktik membuat masyarakat mampu menyediakan keju dengan karya sendiri. Sebanyak $80-100 \%$ dari jumlah peserta menyatakan kemampuan yang baik hingga baik sekali dalam membuat keju setelah praktik dalam kegiatan pengabdian pada masyarakat (Gambar 2).

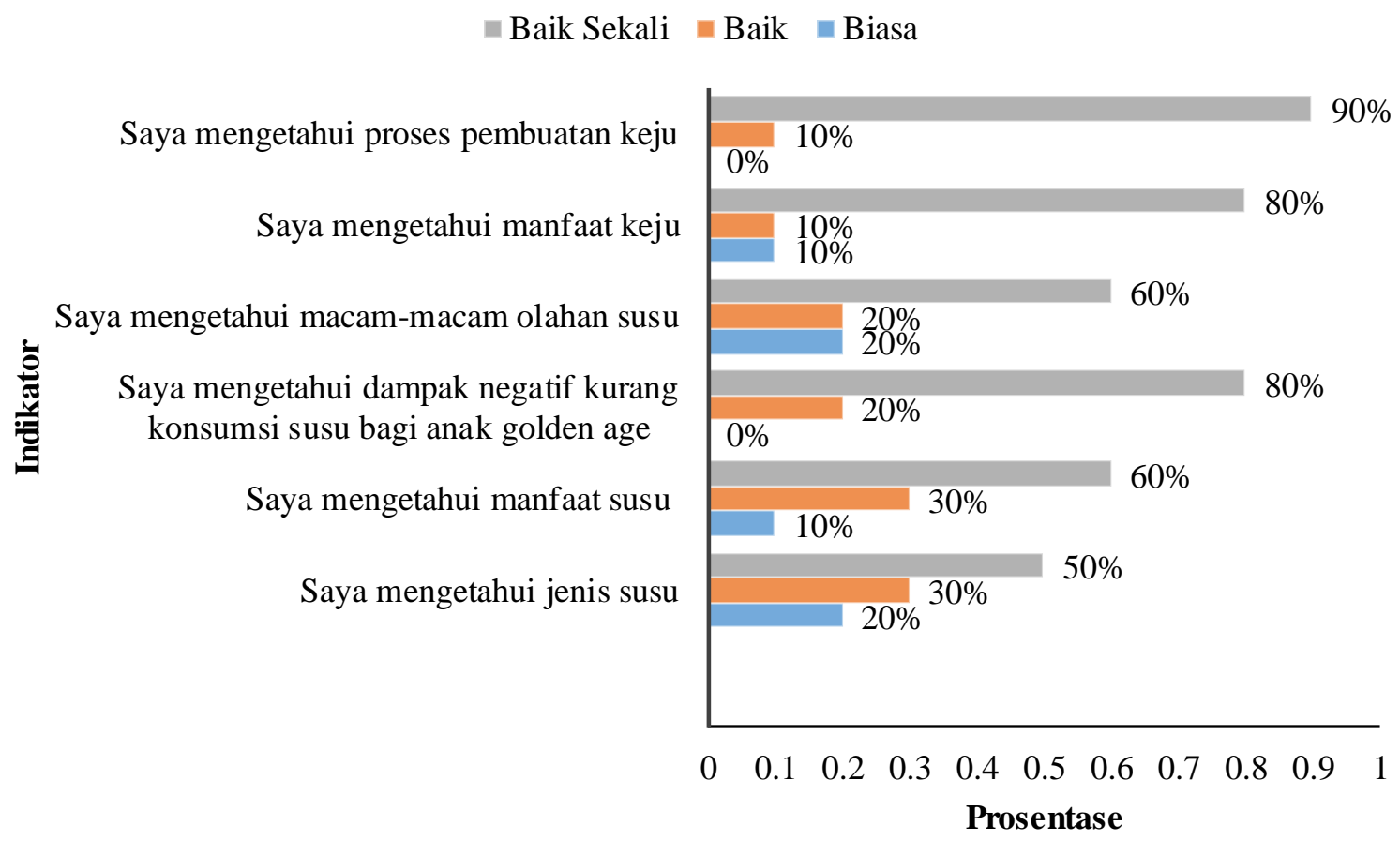

Gambar 2 Prosentase pengetahuan dan pemahaman masyarakat mengenai susu dan keju 
Tingkat pengetahuan dan pemahaman masyarakat terhadap materi yang disampaikan dengan 6 butir pernyataan sangat diterima dengan baik oleh masyarakat. Pada butir pernyataan 1 masih terdapat 20\% masyarakat yang hasil pengetahuan dan pemahamannya meningkat biasa, 30\% meningkat baik, dan 50\% meningkat baik sekali. Butir pernyataan 2 terdapat $10 \%$ tingkat pengetahuan dan pemahamannya meningkat biasa, 30\% meningkat baik, dan $60 \%$ meningkat baik sekali. Pada butir pernyataan 3 terdapat 20\% masyarakat dengan tingkat pengetahuan dan pemahamannya meningkat baik, dan $80 \%$ meningkat baik sekali. Butir pernyataan 4 terdapat $20 \%$ tingkat pengetahuan dan pemahamannya meningkat biasa, 20\% meningkat baik, dan 60\% meningkat baik sekali. Pada butir pernyataan 5 masih terdapat $10 \%$ masyarakat yang hasil pengetahuan dan pemahamannya meningkat biasa, $10 \%$ meningkat baik, dan $80 \%$ meningkat baik sekali. Dan pada butir pernyataan 6 terdapat $10 \%$ tingkat pengetahuan dan pemahamannya meningkat meningkat baik, dan $90 \%$ meningkat baik sekali.

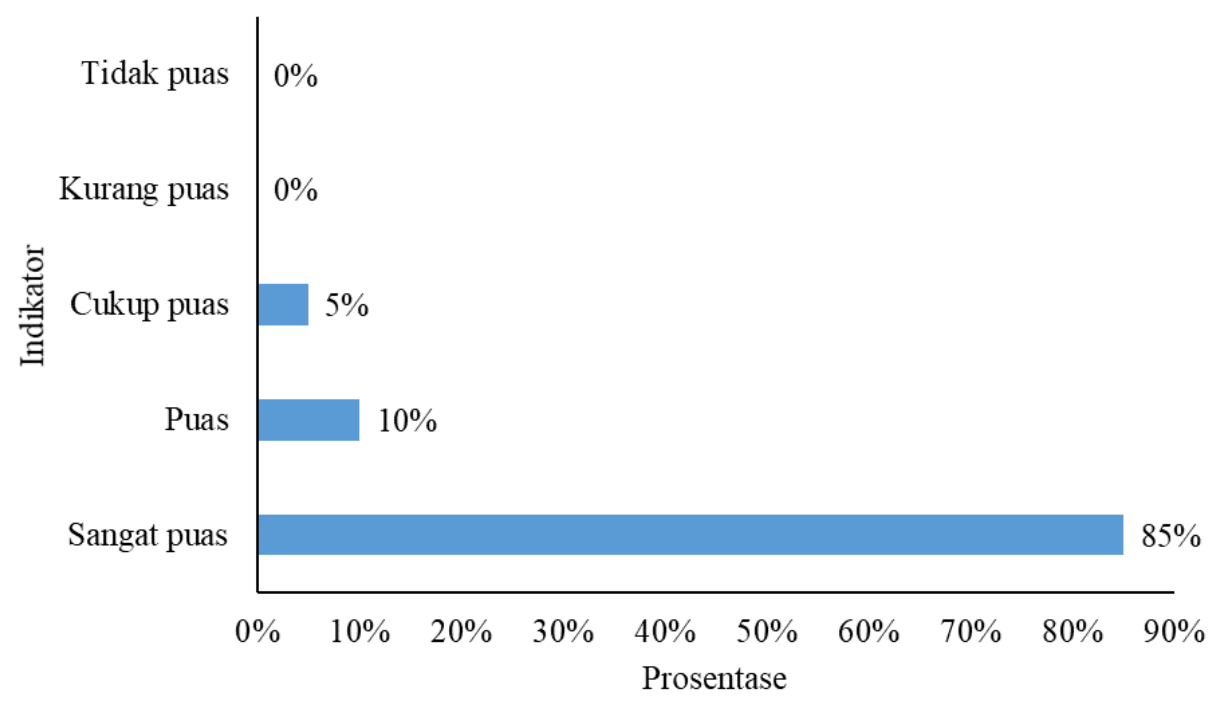

Gambar 3 Tingkat kepuasan masyarakat terhadap kegiatan pengabdian masyarakat

Pengolahan keju yang terbuat dari bahan dasar susu sangat diminati oleh masyarakat dikarenakan proses pengolahannya yang mudah dan sederhana serta bahan baku pembuatannya juga sangat mudah untuk ditemukan di pasar. Masyarakat puas dengan kegiatan ini (Gambar 3). Tingkat kepuasan masyarakat terhadap kegiatan pengabdian masyarakat yang dilaksanakan sangat diterima dengan baik oleh masyarakat. Hal ini dikarenakan persentase masyarakat merasa sangat puas dengan kegiatan yang dilakukan sebanyak $85 \%$, dan terdapat $10 \%$ serta $5 \%$ masyarakat merasa puas dan cukup puas dengan kegiatan tersebut.

\section{KESIMPULAN}

Dapat disimpulkan bahwa kegiatan penyuluhan dan pelatihan pembuatan keju sangat diminati masyarakat karena dapat menambah pengalaman serta pengetahuan mengenai susu dan berbagai macam olahannya salah satunya adalah keju. Masyarakat tidak akan khawatir apabila anak mereka yang berada dalam masa golden age tidak berkeinginan mengkonsumsi susu karena susu dapat diolah menjadi keju dengan tidak mengurangi kandungan gizi yang terdapat pada susu tersebut. 
Kegiatan ini juga dapat menambah kreativitas masyarakat terutama ibu-ibu dalam mengelola asupan gizi yang seimbang bagi kebutuhan nutrisi anak dalam masa golden age. Selain itu, kegiatan pengolahan susu menjadi keju dapat menjadi peluang usaha tambahan bagi masyarakat dalam meningkatkan ekonomi. Diharapkan kegiatan penyuluhan dan pelatihan pengolahan pangan dapat lebih dikembangkan dan bervariasi untuk meningkatkan pengetahuan dan pemahaman masyarakat dalam berbagai bidang dan dapat meningkatkan perekonomian masyarakat sebagai peluang usaha tambahan.

\section{DAFTAR PUSTAKA}

Abdul Aziz, W. (2010). Perancangan media informasi tentang manfaat susu sapi untuk anak-anak [Disertasi]. Universitas Komputer Indonesia.

Afrinis, N., Indrawati, I., \& Farizah, N. (2020). Analisis faktor yang berhubungan dengan kejadian karies gigi anak usia dini. Jurnal Obsesi: Jurnal Pendidikan Anak Usia Dini, 5(1), 763-771.

Damayanti, D. (2013). Makanan anak usia sekolah. Gramedia Pustaka Utama.

Fitri, N. (2020). Pemberdayaan perempuan/ibu tunggal melalui pelatihan pembuatan produk industri rumah tangga halal dan sehat sebagai usaha peningkatan self efikasi diri dalam berwirausaha. Jurnal Abdimas Madani dan Lestari (JAMALI), 2(01), 26-37.

Hidayat, A. A. (2010). Metode penelitian kebidanan dan teknik analisa data, Edisi I. Salemba Medika.

Kertamuda, M. A. (2015). Golden age-strategi sukses membentuk karakter emas pada anak. Elex Media Komputindo.

Louisa, M. (2017). Berbagai manfaat vitamin D. Cermin Dunia Kedokteran, 44(10), 736-740.

Maulani, D. C. (2005). Kiat merawat gigi anak. Elex Media Komputindo.

Negara, J. K., Sio, A. K., Rifkhan, R., Arifin, M., Oktaviana, A. Y., Wihansah, R. R. S., \& Yusuf, M. (2016). Aspek mikrobiologis, serta Sensori (Rasa, Warna, Tekstur, Aroma) pada dua bentuk penyajian keju yang berbeda. Jurnal Ilmu Produksi dan Teknologi Hasil Peternakan, 4(2), 286-290.

Nirmala, I., \& Aisyah, D. S. (2017). Meningkatkan kesadaran pentingnya kecukupan asupan buahbuahan bagi anak melalui kegiatan pelatihan kreasi salad buah di Kecamatan Telukjambe Timur Kabupaten Karawang (Abdimas Di PAUD Kenanga V, TKIT Al-Kaukaba, dan RA Ar-Rahmah Kec. Teluk Jambe Timu. Jurnal Pendidikan Islam Rabbani, 1(1).

Nuryati, N. (2017). Pembelajaran Hadis untuk Anak Usia Dini. In Annual Conference on Islamic Early Childhood Education (ACIECE). 273-284.

Rahmi, P. (2019). Peran Nutrisi Bagi Tumbuh dan Kembang Anak Usia Dini. Jurnal Pendidikan Anak Bunayya, 5(1).

Riwayati, I., Hartati, I., \& Harianingsih, H. (2018). Pelatihan Pembuatan Keju Lunak Alami dan Produk Olahannya Bagi Peternak Sapi di Desa Pengging Kecamatan Banyudono Boyolali. Abdimas Unwahas, 3(2), 26-29.

Siahaan, G., Nasution, E., \& Sihotang, U. (2015). Hubungan kebiasaan senam, asupan kalsium dan Vitamin C dengan densitas massa tulang. Gizi Indonesia, 38(2), 115-124.

Uce, L. (2017). The golden age: Masa efektif merancang kualitas anak. Bunayya: Jurnal Pendidikan Anak, 1(2), 77-92. 
Rahmawida Putri \& Haerul Juhroni. Abdihaz: Jurnal Pengabdian pada Masyarakat. 3(2): 87-95

Widodo, W. (2002). Bioteknologi Fermentasi Susu. Pusat Pengembangan Bioteknologi Universitas Muhammadiyah Malang. 